\title{
Audit Quality And Accrual Quality: Do Big 4 Auditors Indeed Enhance Accrual Quality Of 'Powerful' Clients?
}

Sorah Park, Ewha Womans University, South Korea

\begin{abstract}
External auditors are considered 'watchdogs' which closely monitor corporate financial reporting process and provide guidelines for investors and financial institutions. However, recent accounting scandals in Korea indicate that external auditors may cater their audit reports to their clients' needs. Based on a sample of listed companies on the Korea Stock Exchange from 2001 to 2010, this study finds the evidence consistent with such conjecture. First, large business conglomerates in Korea (so called 'chaebols') audited by Big 4 have lower accrual quality than the others, indicating that Big 4 auditors may not serve as watchdogs to enhance accrual quality of 'powerful' clients. However, powerful clients who pay greater non-audit service fees to Big 4 auditors have higher accrual quality than the others. This result suggests that non-audit services provided by Big 4 may not necessarily harm the quality of accounting information, contrary to the traditional view in the literature.
\end{abstract}

Keywords: Accrual Quality; Audit Quality; External Auditor; Big 4; Chaebol

\section{INTRODUCTION}

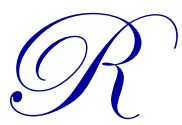

ecently, in Korea, there is a heated debate over the corporate restructuring of companies such as Daewoo Shipbuilding \& Marine Engineering (DSME) and STX Offshore \& Shipbuilding. Regulatory agencies missed the appropriate timing to interfere since these companies did not provide transparent information via fraudulent accounting and window dressing. The consequence of such scandals ultimately harmed their major creditors and investors. The following article ${ }^{1}$ describes this specific case:

"DSME recently corrected its financial statements for 2013 and 2014, during which the company had initially said it had hundreds of billions of won in operating profit. But it later revealed it actually suffered huge losses. Prosecutors are looking into whether the KDB and Deloitte Anjin were complicit in the accounting fraud.

The company has recently come up with a restructuring plan to cut costs and repay debt. While the firm says the deficit was due to increased costs amid the industry-wide slump, shareholders claim corrupt and incompetent management worsened the situation. As of April, some 420 minor shareholders filed a total of seven separate compensation suits with the Seoul Central District Court against the company and its former CEOs, seeking a total of 25 billion won in damages. The plaintiffs said their loss in stock investments resulted from false financial information the company publicly offered."

More interesting (and troubling) fact is that these companies of concern have been audited by Big 4 auditors, which are documented to enhance accounting quality in prior research based on the U.S. market. Auditors are often called corporate accounting 'watchdogs' since they monitor the financial reporting processes and provide insightful information for investors and financial institutions. However, contrary to such beliefs, recent accounting scandals in Korea imply that Big 4 auditors may not improve the accounting quality but rather cater to their clients' needs. For instance, the auditor of STX did not detect their upward earnings manipulation by over 2 quadrillion dollars from

\footnotetext{
${ }^{1}$ The article titled "Daewoo Shipbuilding raided for alleged accounting fraud" is retrieved from The Korea Times, 2016-06-08. 
2007 to 2012. Also, DSME concealed their significant losses for several years, but their auditor did not detect it and never presented the qualified audit opinion from 2010 until now. Such anecdotal evidence leads to the research question of this study. Hence, this paper aims to examine whether Big 4 auditors indeed enhance the accrual quality of 'powerful' clients, which are defined as large business conglomerates in Korea (so called 'chaebols').

Based on a sample of 3,618 firm-years (which consist of 2,805 non-chaebols and 813 chaebols) listed on the Korea Stock Exchanges from 2000 to 2010, this study finds that chaebol firms audited by Big 4 have lower accrual quality than the others. This suggests that Big 4 auditors may have limitations in improving the quality of accounting information of clients who can exert significant power over them. Moreover, greater non-audit fees tend to be related to lower accrual quality on average, consistent with prior research documenting that such business bonding impedes the auditor independence. However, accrual quality of chaebol firms which pay greater amount of nonaudit service fees to Big 4 auditors is shown to be higher than the others. These findings add fresh evidence to the literature as they indicate that non-audit services provided by Big 4, which strengthen the business relation between 'powerful' clients and auditors, may not necessarily harm the quality of accounting information.

This paper makes several contributions to the academic literature. It aims to expand our understanding on the relationship between audit quality and accounting quality. Prior studies have documented that Big 4 audit firms enhance accrual quality and accounting conservatism (e.g., Palmrose 1988, Francis et al. 1999). However, this study provides fresh evidence that non-audit services provided by Big 4 may not necessarily harm the accrual quality of powerful clients. This is contrary to the traditional view that business relations between clients and auditors hurt the independence of external auditors (e.g., Frankel et al. 2002).

Also, this study has important implications for the field. Currently, only field auditors have been penalized for accounting frauds and audit failures. Such practice has not been a fundamental solution to problems related to low fees and fierce competition in the audit industry. However, the congress recently proposed the new legislation in which CEOs of external audit firms are deemed responsible for accounting frauds and consequently may be subject to criminal penalty. This paper provides evidence supporting the recent move towards strict regulations as a means to improve audit quality and therefore protect the capital market participants.

The remainder of this paper is organized as following. Section 2 reviews the related literature and develops hypotheses. Section 3 describes the research methodologies such as sample, variable measurement and research model. Section 4 summarizes the test results and finally Section 5 concludes.

\section{RELATED LITERATURE AND HYPOTHESES}

This paper is related to two strands of accounting literature. First, a number of prior studies find the positive association between audit quality and accounting quality. Audit quality is defined in terms of assurance level - "the probability financial statements contain no material omissions or misstatements" (See DeAngelo 1981, Palmrose 1988). Big $\mathrm{N}$ auditors are generally considered higher quality. For instance, companies audited by Big $\mathrm{N}$ have lower discretionary accruals (Becker et al. 1998, Francis et al. 1999, Boone et al. 2010). Also, only Big N auditors show evidence of reporting conservatism (Francis and Krishnan 1999), and similarly, non-Big N auditors have higher litigation activity than Big N auditors (Palmrose 1988). While prior studies have examined the relation between Big 4 and accounting quality on average, this paper focuses on 'powerful' or 'influential' audit clients who can exert significant power over their auditors. Therefore, the first hypothesis examines whether the accrual quality of powerful clients is enhanced when audited by Big 4 in Korea. It is stated as follows (in null hypothesis):

H1: There is no relationship between Big 4 auditors and accrual quality of powerful clients.

Second, this paper builds on previous studies that examine the effect of non-audit services provided by external auditors. Non-audit services usually include business consulting, valuation, taxation, IT system, litigation support, legal services. Also, the costs of these services are much larger than audit fees. Prior research has studied how nonaudit services provided by external auditors affect accounting quality of clients. For example, Frankel et al. (2002) find that non-audit fees are positively associated with the magnitude of discretionary accruals, while audit fees are negatively related to earnings management indicators. These results suggest that such business relation could hurt 
the independence of external auditors and ultimately decrease the transparency of financial reporting. Hence, external auditors are prohibited to take on such services for their audit clients in some countries. For example, in U.S., based on Section 201 of the Sarbanes-Oxley Act (2002), the Public Company Accounting Oversight Board (PCAOB) prohibits the following specific services: bookkeeping or other services related to the accounting records or financial statements of the audit client; financial information systems design and implementation; appraisal or valuation services, fairness opinions, or contribution-in-kind reports; actuarial services; internal audit outsourcing services; management functions or human resources; broker or dealer, investment adviser, or investment banking services; legal services and expert services unrelated to the audit; and any other service that the new PCAOB determines, by regulation, is impermissible. However, in Korea, this is still in practice; namely, external auditors can perform non-audit services for their audit clients. Such characteristic of Korean market makes it particularly suited to my investigation. Hence, the second hypothesis examines how the non-audit services provided by Big 4 affects the accrual quality of powerful clients, which is stated as follows:

H2: There is no relationship between non-audit services provided by Big 4 and accrual quality of powerful clients.

\section{DATA AND METHODOLOGIES}

\subsection{Sample}

The sample used in the study consists of listed companies on KOSPI and KOSDAQ from 2001 to 2010. The sample period ends in 2010 because the new accounting standard (Korean International Financial Reporting Standard; KIFRS) was adopted in 2011. The financial variables used in data analyses are collected from the TS2000 database. ${ }^{2}$

The following data requirements are imposed on the initial sample. First, firms in financial and insurance industries are deleted since their financial statements are not comparable to the other industries. Second, firms with nonDecember fiscal year-end, impaired capital or negative total assets are deleted. Lastly, firms without data necessary to calculate accrual quality for five consecutive years are deleted. The final sample contains 2,805 non-chaebol firmyears and 813 chaebol firm-years. For a regression purpose, all variables are winsorized at top $99 \%$ and bottom $1 \%$. Sampling procedure is summarized in Table 1.

Table 1. Sampling Procedure

\begin{tabular}{l|c|c}
\hline $\begin{array}{l}\text { Firm-years available on TS2000 and in KOSPI \& KOSDAQ from 2001 to } \\
2010\end{array}$ & No. of Non-Chaebols & No. of Chaebols \\
\hline Less: Financial industries \& non-December year-ends \& capital impairment & 707 & 1,868 \\
\hline Less: No 5-year data for accounting quality & 4,411 & 840 \\
\hline Less: Missing data for other variables & 2,526 & 67 \\
\hline Final sample & 2,805 & 813 \\
\hline
\end{tabular}

\subsection{Variable Measurement}

\section{(1) Accounting Quality}

Following Francis et al. (2005), accrual quality is measured as the variability of unexplained accruals from the Dechow and Dichev (2002) and McNichols (2002) models. The following cross-sectional model is estimated annually:

$$
\mathrm{CAcc}_{\mathrm{t}}=\alpha_{1, \mathrm{t}}+\alpha_{2, \mathrm{t}} C F O_{t-1}+\alpha_{3, \mathrm{t}} \operatorname{CFO}_{t}+\alpha_{4, \mathrm{t}} C F O_{t+1}+\alpha_{5, \mathrm{t}} \Delta R e v_{t}+\alpha_{6, \mathrm{t}} P P E_{t}+\varepsilon_{\mathrm{t}}
$$

\footnotetext{
2 TS2000 is equivalent to Compustat in U.S., covering all publicly listed firms in Korea.
} 
where $C A c c$ is current accruals or the change in working capital, $C F O$ is operating cash flows, $\triangle R e v$ is the change in revenues, $P P E$ is property, plant and equipment, and all variables are scaled by total assets. Equation (1) is estimated separately for each industry group, defined as the two-digit KSIC code, if the industry has at least 10 firms in year $t$.

The accrual quality measure $(A Q)$ for firm $i$ in year $t$ is the standard deviation of firm $i$ 's unexplained current accruals (the residuals from model (1)) over the last five years. High $A Q$ represents poor accrual quality since it implies high uncertainty in the mapping of accrual to cash flow.

\section{(2) Powerful Audit Clients}

In this paper, powerful client is proxied by large, family-controlled business groups (so called 'chaebols') in Korea. Chaebol groups are composed of owner-managed companies in which controlling shareholder or founder family member is an executive or a chairman on the board (Jeong and Bae 2007). Family-controlled business groups account for a significant proportion of gross national product of Korea and influence great part of the national economy.

These companies have significant related party transactions among subsidiaries, and the Fair Trade Committee restricts such mutual contributions. The committee announces the list of companies which are restricted on mutual contribution based on their total assets in April every year. Hence, the companies on this list are classified as chaebols (i.e., chaebol $=1$ ) and the others as non-chaebols (i.e., chaebol=0).

\subsection{Research Models}

$$
\begin{aligned}
& A Q_{j t}=\gamma_{0 t}+\gamma_{1 t} \text { Big }_{j t}+\gamma_{2 t} \text { Chaebol }_{j t} * \text { Big }_{j t}+\gamma_{3 t} \text { Size }_{j t}+\gamma_{4 t} \text { Debt }_{j t}+\gamma_{5 t} \text { ROA }_{j t}+\gamma_{6 t} \text { Loss }_{j t}+ \\
& \text { Year FE }+ \text { Ind FE }+\epsilon_{j t} \\
& A_{j t}=\gamma_{0 t}^{\prime}+\gamma^{\prime}{ }_{1 t} \text { Big }_{j t}+\gamma^{\prime}{ }_{2 t} \text { NonAudit }_{j t}+\gamma^{\prime}{ }_{3 t} \text { Big }_{j t} * \text { NonAudit }_{j t}+\gamma^{\prime}{ }_{4 t} \text { Chaebol }_{j t}+ \\
& \gamma^{\prime}{ }_{5 t} \text { Big }_{j t} * \text { Chaebol }_{j t} * \text { NonAudit }_{j t}+\gamma^{\prime}{ }_{6 t} \text { Size }_{j t}+\gamma^{\prime}{ }_{7 t} \text { Debt }_{j t}+\gamma^{\prime}{ }_{8 t} \text { ROA }_{j t}+\gamma^{\prime}{ }_{9 t} \text { Los }_{j t}+ \\
& \text { Year FE }+ \text { Ind FE }+\epsilon_{j t}
\end{aligned}
$$

Hypotheses (1) and (2) are tested based on the models (2) and (3), respectively. In both models, the dependent variable is $A Q$, defined in the previous section. Big 4 is set to 1 if a firm $j$ 's auditor is Samjong KPMG, Samil PWC, Deloitte Anjin, or Ernst \& Young Hanyoung, and 0 elsewhere. NonAudit $j_{j t}$ is the natural logarithm of non-audit service fees, which is retrieved from TS2000 database. It is set to zero if the fee data is missing.

Also, a standard set of controls are included in the regression analyses. First, firm size ( Size $\left._{j t}\right)$ is measured as natural logarithm of a firm's total assets. Large firms have greater political costs and consequently they have greater incentives to manage earnings than small firms (Moses 1987). By contrast, large firms are less likely to manage earnings since there is more available information and less information asymmetry for large firms (Albrecht and Richardson 1990). Debt ${ }_{j t}$ is measured as total liabilities divided by total assets. Higher leverage is shown to be related to earnings management in order to avoid debt covenant violation (Defond and Jiambalvo 1994). Next, $R O A_{j t}$ and $L o s s_{j t}$ are added to control the effect of firm profitability on accounting quality. Lastly, year fixed effects and industry fixed effects are included in the models.

\section{TEST RESULTS}

\subsection{Descriptive Statistics}

Table 2 provides the summary statistics of key variables for non-chaebols and chaebols, separately. First, the mean $A Q$ is 0.11 for non-chaebols and 0.09 for chaebols, implying that accrual quality of non-chaebols is generally lower than chaebols without any control variable. This seems to be due to their information environment, for instance, $84 \%$ of chaebols are audited by Big 4 whereas only $46 \%$ of non-chaebols are audited by Big 4 . Also, the summary 
statistics show that these groups are different in nature. Chaebol firms are larger, more levered, and more profitable (i.e., higher $R O A$ and lower incidence of reporting loss) than non-chaebol firms, on average.

Table 2. Summary Statistics

\begin{tabular}{|c|c|c|c|c|c|c|}
\hline \multicolumn{7}{|c|}{ Panel A: Chaebol $=0$} \\
\hline Variable & $\mathbf{N}$ & Mean & Std Dev & 25th Pctl & Median & 75th Petl \\
\hline $\mathrm{AQ}$ & 2805 & 0.1146 & 0.0871 & 0.0568 & 0.0901 & 0.1406 \\
\hline Big4 & 2805 & 0.4602 & 0.4984 & 0 & 0 & 1 \\
\hline Size & 2805 & 12.080 & 0.9919 & 11.4282 & 12.0137 & 12.6799 \\
\hline Debt & 2805 & 0.4284 & 0.1909 & 0.2865 & 0.4261 & 0.5648 \\
\hline ROA & 2805 & 0.0233 & 0.0843 & 0.0063 & 0.0338 & 0.0659 \\
\hline Loss & 2805 & 0.2011 & 0.4009 & 0 & 0 & 0 \\
\hline \multicolumn{7}{|c|}{ Panel B: Chaebol=1 } \\
\hline Variable & $\mathbf{N}$ & Mean & Std Dev & 25th Pctl & Median & 75th Pctl \\
\hline AQ & 813 & 0.0885 & 0.0697 & 0.0418 & 0.0684 & 0.1118 \\
\hline Big4 & 813 & 0.8393 & 0.3673 & 1 & 1 & 1 \\
\hline Size & 813 & 14.1475 & 1.3575 & 13.1669 & 14.2190 & 15.0710 \\
\hline Debt & 813 & 0.4880 & 0.1882 & 0.3505 & 0.5151 & 0.6273 \\
\hline ROA & 813 & 0.0423 & 0.0732 & 0.0146 & 0.0436 & 0.0793 \\
\hline Loss & 813 & 0.1205 & 0.3257 & 0 & 0 & 0 \\
\hline
\end{tabular}

\subsection{Hypothesis (1)}

First hypothesis examines the relationship between Big 4 auditors and accrual quality of powerful clients. I perform the regression analyses based on two sub-samples: non-chaebol firms versus chaebol firms. The test results are presented in the first and second columns of Table 3. For non-chaebol subsample, the regression coefficient on Big 4 dummy variable is negative and statistically significant at $1 \%$ level $(-0.0074, t$-value $=-2.61)$. This implies that Big 4 auditors significantly decrease the variability of unexplained accruals, in other words, improve the accounting quality. On the contrary, for chaebol subsample, the regression coefficient on Big 4 is negative but marginally significant at $10 \%$ level $(-0.0104, t$-value $=-1.70)$.

In order to confirm whether such difference between two groups is significant, the regression model that includes the interaction term (Big4*Chaebol) is estimated based on the full sample. The regression coefficient on the interaction term is positive and statistically significant at $1 \%$ level $(0.0102, t$-value $=2.69)$, indicating that chaebol firms which are audited by Big 4 have higher variability in mapping between accruals and cash flows i.e., lower accounting quality. This suggests Big 4 auditors may have some limitations in improving the quality of accounting information of clients who can exert significant power over them.

Table 3. (Hypothesis 1) Big 4 \& Accounting Quality for Chaebol/Non-Chaebol Firms

\begin{tabular}{|c|c|c|c|c|c|c|}
\hline \multirow[b]{2}{*}{ Variable } & \multicolumn{2}{|c|}{ Non-Chaebol Firms } & \multicolumn{2}{|c|}{ Chaebol Firms } & \multicolumn{2}{|c|}{ Full Sample } \\
\hline & Parameter & t Value & Parameter & t Value & Parameter & t Value \\
\hline Intercept & 0.2288 & $12.2^{* * *}$ & 0.2175 & $8.99^{* * *}$ & 0.2197 & $15.57^{* * *}$ \\
\hline Big4 & -0.0074 & $-2.61^{* * *}$ & -0.0104 & $-1.70^{*}$ & -0.0047 & $-1.79^{*}$ \\
\hline Big $4 *$ Chaebol & & & & & 0.0102 & $2.69^{* * *}$ \\
\hline Size & -0.0123 & $-7.97^{* * *}$ & -0.0120 & $-7.19^{* * *}$ & -0.0118 & $-10.72^{* * *}$ \\
\hline Debt & 0.0441 & $5.56^{* * *}$ & 0.0696 & $5.58^{* * *}$ & 0.0454 & $6.77^{* * *}$ \\
\hline ROA & -0.0451 & $-1.87^{*}$ & -0.0252 & -0.66 & -0.0363 & $-1.76^{*}$ \\
\hline Loss & 0.0190 & $3.92^{* * *}$ & 0.0129 & 1.59 & 0.0195 & $4.65^{* * *}$ \\
\hline Fixed Effects & \multicolumn{2}{|c|}{ Year, Industry } & \multicolumn{2}{|c|}{ Year, Industry } & \multicolumn{2}{|c|}{ Year, Industry } \\
\hline $\mathrm{N}$ & \multicolumn{2}{|c|}{2805} & \multicolumn{2}{|c|}{813} & \multicolumn{2}{|c|}{3618} \\
\hline Adj. R2 & \multicolumn{2}{|c|}{0.1155} & \multicolumn{2}{|c|}{0.3057} & \multicolumn{2}{|c|}{0.1573} \\
\hline
\end{tabular}




\subsection{Hypothesis (2)}

Second hypothesis investigates the accounting quality of powerful clients audited by Big 4 which provide a greater level of non-audit services. Table 4 presents the test results of the regression analyses based on two sub-samples of non-chaebol firms and chaebol firms. For both sub-samples, the regression coefficients on Non-audit fee are positive and statistically significant at 5\% and 1\% level. This indicates that higher non-audit service fees are associated with higher variability of unexplained accruals (i.e., lower accrual quality), consistent with prior research.

Moreover, the coefficients on the interaction term Big $4 *$ Non-audit are negative, marginally significant at $10 \%$ level for non-chaebols and statistically significant at $1 \%$ level for chaebols. These findings imply that non-audit services provided by Big 4 for chaebol clients are related to higher accounting quality. The difference is significant as the regression coefficient on the three-way interaction (Big4*Chaebol*Non-audit) is negative and marginally significant at $10 \%$ level, as shown in the full sample results. This is new to the literature since non-audit services provided by Big 4 may not necessarily decrease the quality of accounting information, specifically for chaebol firms which represent the powerful clients.

Table 4. (Hypothesis 2) Big 4, Non-Audit Service Fees, \& Accounting Quality for Chaebol/Non-Chaebol Firms

\begin{tabular}{|c|c|c|c|c|c|c|}
\hline \multirow[b]{2}{*}{ Variable } & \multicolumn{2}{|c|}{ Non-Chaebol Firms } & \multicolumn{2}{|c|}{ Chaebol Firms } & \multicolumn{2}{|c|}{ Full Sample } \\
\hline & Parameter & t Value & Parameter & t Value & Parameter & t Value \\
\hline Intercept & 0.2414 & $11.87^{* * *}$ & 0.2178 & $8.29^{* * *}$ & 0.2333 & $15.03^{* * *}$ \\
\hline Big4 & -0.0036 & -1.17 & -0.0026 & -0.38 & -0.0032 & -1.16 \\
\hline Non-audit & 0.0000 & $2.41^{* *}$ & 0.0000 & $2.64^{* * *}$ & 0.0000 & $3.26^{* * *}$ \\
\hline Chaebol & & & & & 0.0131 & $3.34^{* * *}$ \\
\hline Big4*Non-audit & -0.0000 & $-1.77^{*}$ & -0.0000 & $-2.65^{* * *}$ & -0.0000 & $-2.49^{* *}$ \\
\hline Big $4 *$ Chaebol $*$ Non-audit & & & & & -0.0000 & $-1.87^{*}$ \\
\hline Size & -0.0134 & $-8.25^{* * *}$ & -0.0119 & $-6.66^{* * *}$ & -0.0130 & $-10.58^{* * *}$ \\
\hline Debt & 0.0391 & $4.72^{* * *}$ & 0.0650 & $5.27^{* * *}$ & 0.0449 & $6.46^{* * *}$ \\
\hline ROA & -0.0523 & $-1.99^{* *}$ & 0.0278 & 0.69 & -0.0288 & -1.28 \\
\hline Loss & 0.0188 & $3.66^{* * *}$ & 0.0120 & 1.48 & 0.0192 & $4.33^{* * *}$ \\
\hline Fixed Effects & \multicolumn{2}{|c|}{ Year, Industry } & \multicolumn{2}{|c|}{ Year, Industry } & \multicolumn{2}{|c|}{ Year, Industry } \\
\hline $\mathrm{N}$ & \multicolumn{2}{|c|}{2555} & \multicolumn{2}{|c|}{734} & \multicolumn{2}{|c|}{3289} \\
\hline Adj. R2 & \multicolumn{2}{|c|}{0.1256} & \multicolumn{2}{|c|}{0.3147} & \multicolumn{2}{|c|}{0.1492} \\
\hline
\end{tabular}

\section{CONCLUSIONS}

External auditors monitor the accounting information prepared and disclosed by their audit clients. In the developed capital markets, external auditors are considered 'watchdogs' which closely monitor a firm's financial reporting process. However, the situation may be different in Korea. Recent accounting scandals indicate that external auditors may cater their audit reports to their client needs.

This paper provides the empirical evidence that is consistent with such conjecture, based on the sample of 2,805 non-chaebol firm-years and 813 chaebol firm-years listed on KOSPI and KOSDAQ from 2000 to 2010. First, chaebol firms that are audited by Big 4 have lower accounting quality than the others, suggesting that Big 4 auditors may have some limitations in improving the quality of accounting information of some 'powerful' clients. Next, accrual quality of chaebol firms which pay a greater amount of non-audit service fees to Big 4 auditors is higher than the others. These findings indicate that non-audit services provided by Big 4 may not necessarily harm the accrual quality.

However, this study has some limitations. While this paper uses the chaebol firms to proxy for powerful audit clients, such proxy may not be available in other countries since these family firms have strong ties with national economy and politics. Future studies may thus pursue other potential proxies to study their accrual quality. Also, the role of corporate governance and/or legal environments could be examined in future research. 


\section{AUTHOR BIOGRAPHY}

Sorah Park (Corresponding author): Ph.D., Assistant Professor of Accounting at Ewha School of Business, Ewha Womans University, Seoul, Korea.

\section{REFERENCES}

Albrecht, W. D., \& Richardson, F. M. (1990). Income smoothing by economy sector. Journal of Business Finance \& Accounting, 17(5), 713-730.

Becker, C. L., DeFond, M. L., Jiambalvo, J., \& Subramanyam, K. R. (1998). The effect of audit quality on earnings management. Contemporary Accounting Research, 15(1), 1-24.

Boone, J. P., Khurana, I. K., \& Raman, K. K. (2010). Do the Big 4 and the second-tier firms provide audits of similar quality?. Journal of Accounting and Public Policy, 29(4), 330-352.

DeAngelo, L. E. (1981). Auditor size and audit quality. Journal of Accounting and Economics, 3(3), 183-199.

Dechow, P. M., \& Dichev, I. D. (2002). The quality of accruals and earnings: The role of accrual estimation errors. The Accounting Review, 77(s-1), 35-59.

DeFond, M. L., \& Jiambalvo, J. (1994). Debt covenant violation and manipulation of accruals. Journal of Accounting and Economics, 17(1-2), 145-176.

Francis, J. R., Maydew, E. L., \& Sparks, H. C. (1999). The role of Big 6 auditors in the credible reporting of accruals. Auditing: a Journal of Practice \& Theory, $18(2), 17-34$.

Francis, J. R., \& Krishnan, J. (1999). Accounting accruals and auditor reporting conservatism. Contemporary Accounting Research, 16(1), 135-165.

Francis, J., LaFond, R., Olsson, P., \& Schipper, K. (2005). The market pricing of accruals quality. Journal of Accounting and Economics, 39(2), 295-327.

Francis, J. R., \& Wang, D. (2008). The joint effect of investor protection and Big 4 audits on earnings quality around the world. Contemporary Accounting Research, 25(1), 157-191.

Frankel, R. M., Johnson, M. F., \& Nelson, K. K. (2002). The relation between auditors' fees for nonaudit services and earnings management. The Accounting Review, 77(s-1), 71-105.

Jeong, J. W., \& Bae, G. S. (2007). Long-run stock price performance of the firms that grant stock options and the separation of ownership and management. Korean Financial Management Research, 24(1), 149-182. [Printed in Korean]

Lim, C. Y., \& Tan, H. T. (2008). Non-audit service fees and audit quality: The impact of auditor specialization. Journal of Accounting Research, 46(1), 199-246.

Moses, O. D. (1987). Income smoothing and incentives: Empirical tests using accounting changes. The Accounting Review, 358377.

Palmrose, Z. V. (1988). 1987 Competitive Manuscript Co-Winner: An analysis of auditor litigation and audit service quality. The Accounting Review, 55-73. 


\section{NOTES}

